\title{
Acting Out of Compassion, Egoism, and Malice: A Schopenhauerian View on the Moral Worth of CSR and Diversity Management Practices
}

\author{
Thomas Köllen ${ }^{1}$
}

Received: 21 May 2014/ Accepted: 6 March 2015/Published online: 14 March 2015

(C) Springer Science+Business Media Dordrecht 2015

\begin{abstract}
In both their external and internal communications, organizations tend to present diversity management (DM) approaches and corporate social responsibility initiatives as a kind of morally 'good' organizational practice. With regard to the treatment of employees, both concepts largely assume equality to be an indicator (as well as a goal) of organizational 'goodness', e.g. in terms of equal treatment, or affording equal opportunities. Additionally, research on this issue predominantly refers to prescriptive and imperative moralities that address the initiatives themselves, and values them morally. Schopenhauer opposes these moralities by conceptualizing morality as exclusively being based on the incentives of acting instead of the actions themselves. He identifies egoism, compassion, and malice as the sole incentives for every human action, whereby only those actions solely motivated by compassion can be ascribed genuine moral worth. In this context, this article shows that from a Schopenhauerian perspective, CSR and DM initiatives only have a genuine moral worth in so far as the individuals who have initiated or supported their implementation were exclusively motivated by compassion. Stressing the narrative of a business case, if utilized as a façade for true compassion that attaches economic legitimacy to these initiatives, does not necessarily harm their moral worth. The approach and the findings developed in this paper contribute to the discourse on the ethical behavior of organizations, as well as to the discourse on CSR and DM.
\end{abstract}

Thomas Köllen

thomas.koellen@wu.ac.at

1 Department Management, Institute for Gender and Diversity in Organizations, Vienna University of Economics and Business (WU), Welthandelsplatz 1, 1020 Vienna, Austria
Keywords Business case - Compassion, egoism, and malice $\cdot$ Corporate social responsibility $\cdot$ Diversity management $\cdot$ Justice and loving kindness $\cdot$ Mitleid

\section{Introduction}

Corporate social responsibility (CSR) and diversity management (DM) are two closely linked concepts with different backgrounds and geneses. Since the 1950s, discourse on CSR, and on the different layers of social responsibilities of economic operators, has intensified in Western countries (Carroll 1999). The 1990s saw a renewed impetus given to academic publications on CSR, mainly due to an increase in corporate scandals, which showed the potentially negative consequences of 'corporate social irresponsibility' (Morsing and Schultz 2006). An oft-cited example is the case of Shell and its plans to sink the oil storage buoy Brent Spar in the North Sea, and its operations in Nigeria (Livesey 2001). Nowadays CSR is a widespread label that is predominantly utilized by large, multinational companies, because, at least in the eyes of the public, they are usually more prone to acting in an 'irresponsible manner', than locally anchored SMEs (Nielsen and Thomsen 2009). These companies use CSR as an umbrella term for their corporate actions on environmental and social sustainability, the latter targeting the "labor conditions of the company itself and its suppliers, [and] the contribution to social problems of society at large" (Graafland et al. 2004, p. 147). Underlying this expression is the assumption, or assertion, that even private companies should have a public responsibility, an assumption that partially equates CSR with the concept of corporate citizenship (Carroll 1998). Broadly speaking, this responsibility for the societies in which the company is operating is a responsibility for maintaining or ameliorating the working 
and living conditions of the people that live in these societies, especially of those who work for the company (Garriga and Melé 2004; Goodpaster 1983). In the last few decades, a greater environmental awareness has come into play in the field of CSR, and a more sustainable use of natural resources has become imperative when implementing CSR measures (Babiak and Trendafilova 2011; Moon 2007). Although CSR is difficult to define as an exact concept with concrete organizational actions (Dahlsrud 2008), in general, it is a double counterpoint to the image of the capitalistic industrial corporations of the 19th century that massively exploited their workers and the environment (Shaw 2009). Despite aiming at "taming" capitalism in a certain way, the concept is usually embedded into an understanding of taking these actions without harming the company's profitability (Scott 2007).

Diversity management, on the other hand, is a much newer management concept that, in contrast to CSR, clearly emerged in the USA and nowadays diffuses into Western capitalist countries. After the elimination of affirmative action obligations in the USA in the 1980s, DM took its place in terms of handling workplace discriminations (Gilbert et al. 1999; Kelly and Dobbin 1998). Affirmative actions were aimed at overcoming workplace discrimination and job segregation for blacks and women. This is the reason why, at least in the USA, gender and race are still by far those dimensions of diversity that receive the most attention (Herring 2009). Nevertheless, DM can include a much broader spectrum of workforce diversity, including additional dimensions of diversity such as religion, sexual orientation, age, disability status, nationality, etc. Similar to CSR, DM is also a controversial concept with numerous potential definitions that cover different dimensions of reference, different organizational goals, and different ways of reaching these goals (Tatli 2011; Tatli et al. 2012). However, DM exceeds the anti-discriminatory intention of affirmative action programs, at least by trend, by assuming an economic benefit from managing workforce diversities (Dass and Parker 1999). As antidiscrimination and the inclusion of a diverse workforce can easily be subsumed into socially responsible behavior, in practice, companies very often treat both concepts together. In their external communication, companies mostly publish their closely linked CSR Reports and Diversity Reports; some companies even label diversity as one part of their CSR approach (Coupland 2006; Grosser and Moon 2008; Holton 2005; Idowu and Towler 2004).

Both, CSR and DM are already currently widespread approaches amongst Western companies, but their diffusion is still increasing, especially outside the USA (Danilovic et al. 2013; Lauring 2013). This leaves open the question of the reason for this 'success story'. There exists a huge amount of literature that analyzes concrete economic benefits that can work as motives for the implementation of both (McGuire et al. 1988; Singal 2014). Another stream of research tries to explain the global diffusion of CSR and DM in a neo-institutional way alongside various isomorphisms (Matten and Moon 2008). Furthermore, some research elaborates on why companies should implement one approach or another because of moral reasons, but these arguments often remain imperative and intuitive, as they evaluate corporate actions themselves as 'good' or 'evil' (Gotsis and Kortezi 2013; Jones et al. 2013). In practice, companies almost always label their CSR and DM activities as in some way morally or ethically 'good' activities, and, in their internal and external communication, often try to project the estimated 'goodness' of these actions onto the actors themselves, aiming at giving the company a general label of ethical 'goodness'. An example for this is the following line of argumentation: Donating money for seriously ill children is assumed to be morally 'good'; McDonalds donates money for seriously ill children; McDonalds therefore conducts a morally 'good' action; McDonalds what it follows, is morally 'good'. This example shows that attaching the label of moral 'goodness' is scarcely that straightforward, as we neither know anything about McDonalds' motivation to donate the money, nor about other activities of McDonalds. So it is highly questionable whether a moral label really can be attached to either the action or the actor. Additionally, were the moral goodness of the action itself to be stated outright, this line of argument and the resulting conclusion would be formally invalidated, unless one were to add the dubious premise that any conductor of a morally good action is morally good.

Against this background, this paper critically reflects this 'goodness' or 'evilness' in a way that focuses on the genesis of corporate CSR and DM activities, instead of addressing the outcome of this process (i.e., the concrete CSR or DM practices or initiatives). An adequate philosophical system for theoretically framing, this undertaking can be found in the moral philosophy of Arthur Schopenhauer (1841b). Thus, in the following pages, the core elements of his moral philosophy will be outlined. Subsequently, it will be discussed how far organizations or companies can be seen as legitimate moral agents and what restrictions have to be derived for judging them morally for their actions. After this, the motivations of organizations for implementing DM or CSR practices are outlined and brought together with the moral categorization of Schopenhauer's ethic. It will be shown that the label of morally "good" corporate behavior cannot, in most cases, and at least in the way most companies use it, withstand a Schopenhauerian categorization of 'moral goodness', because most actions derive from an egoistic motivation. Nevertheless, moral goodness can be identified within the process of implementing CSR or DM initiatives on the level of individual actors, who sometimes drive forward the process of implementation because of reasons of compassion [German: Mitleid]. This driving forward might be achieved by 
communicating an overstated prognosis, or even knowingly communicating a false prognosis about the positive economic outcome of such initiatives (i.e., by lying). However, since the motivation is the crucial indicator for morality in a Schopenhauerian moral evaluation, genuine moral worth can then only be ascribed to the action itself, as long as no individual is knowingly or intentionally harmed by it (e.g., were these actions to cause business losses or reduced profit, the shareholders of the company in question would be harmed; in case of these actions merely not increasing profit, no harm has been done as a status quo has been maintained, nothing has changed and the individuals in question have not been harmfully impacted). Although applying business case considerations as motivation would fall outside the scope of Schopenhauerian morally worthy actions, this motivation is sometimes merely a façade for true compassion.

In focusing on the individuals who are involved in the processes of implementing and shaping organizational DM and CSR initiatives, this paper enriches the discourse on the moral 'judgeability' of CSR and DM with a new facet. Tracing back these initiatives to individuals' motivations allows a new perspective to be gained in terms of discussing their moral worth, and it opens up a new way in which to morally evaluate organizational practices.

\section{Schopenhauer on the Incentives of Human Acting}

Schopenhauer describes egoism, compassion, and malice as the only incentives of every human action, whereby compassion is the only driving force that makes an action born of this motivation a morally good action. Schopenhauer opposes the principle that ethics is the science that states how people ought to behave. This imperative form of ethics, he states, applies only to theological morality, a morality that will be discussed later in this article. "By contrast, I set for ethics the purpose of interpreting, explaining, and reducing to their ultimate ground humanś ways of acting, which from a moral view are extremely varied, [... and to investigate empirically] whether there are any actions at all to which we must grant genuine moral worth" (Schopenhauer 1841b, p. 201). In doing so, he explored, in his time, a new avenue of categorizing behavior in a moral way, and he distanced himself from Kant's non-empirical morality that is based on reason and duty (Dierksmeier 2013; Mestrovic 1989) as well as from other prescriptive ethical theories, such as utilitarianism (Cartwright 2008).

\section{Egoism}

Schopenhauer identifies egoism as the fundamental incentive for human behavior; egoism he defines as the "urge for existence and well-being" (Schopenhauer 1841b, p. 202) that, as its ultimate object, has one's personal well-being and woe.

Egoism by its nature is boundless; the human wills unconditionally to preserve his existence; wills it unconditionally free of pains, among which are included all want and privation; wills the greatest possible amount of well-being, and wills every pleasure of which he is capable, even seeks wherever possible to develop new capacities for pleasure. Everything which opposes the striving of his egoism provokes his animosity, anger, hate: he will seek to annihilate it as his enemy (Ibid., 1841b, p. 202).

As a hyperbole for people's boundless egoism, (which he actually later doubts to be hyperbole), Schopenhauer states: "Many a person would be capable of beating another to death merely to grease his boots with the victim's fat" (Ibid., 1841b, p. 204). As a fig leaf that covers up omnipresent egoism in everyday life people apply politeness, "the conventional and systematical denial of egoism in the trifles of daily intercourse, [a certainly accepted] hypocrisy" (Ibid., 1841b, p. 203). "Since egoism unconditionally pursues its ends when either it is not opposed by an external force, among which may be counted any fear, be it of earthly or supernatural powers, or by the genuine moral incentive, then, to the detriment of all, 'the war of all against all would be order of the day among the countless mobs of egoistic individuals" (Ibid., 1841b, p. 204). External forces, primarily, are state authorities (such as police and the justice system), religious authorities, and the general public "authority". The state whose sole purpose is "to protect individuals from one another and the whole from external enemies" (Ibid., 1841b, p. 221) penalizes violations of the laws (made by itself) in this life. Thus, behavior that is only motivated by obeying state laws is egoistic behavior, as its underlying incentive is the avoidance of sanctions and related personal woe. Religions, as the most common interpretative systems that refer to supernatural powers, usually claim to penalize violations against their "laws" or to reward their observance in another life (or hereafter). These "laws" mostly appear in a dogmatic way and often try to adumbrate completely an individual's idea of having a conscience guiding his or her actions. "By conscience religious people of any faith frequently understand nothing other than the dogmas and precepts of their religion and the self-examination they undertake based on these"(Ibid., 1841b, p. 199). Thus, as this kind of theological "morality" is based on a system of punishment and reward in this or (mostly) another world, human behavior that is nothing more than obeying these rules cannot be anything else but egoistic, because the incentive then is the individual's well-being in this or in another life. The third authority gains power from the "need for a good name or 
civil honor necessary for progressing in the world" (Ibid., 1841 b, p. 195). Public opinion watches everyone's steps based "on the fundamental principle: operari sequitur esse ("What we do follows from what we are')" (Schopenhauer $1841 \mathrm{a}$, p. 122), and "never forgives a single misstep" (Schopenhauer 1841b, p. 195). What is wrong and right in this context, can differ between times and societies (Demuijnck 2014), but the observance of these rules definitely cannot be categorized a morally 'good', as this is only due to the egoistic motive of maintaining a positive image.

\section{Compassion}

As the only genuine moral incentive Schopenhauer cites compassion [Mitleid]:

when the ultimate motivating ground for an action or omission lies directly and exclusively in the wellbeing and woe of some other person [...and] intends nothing but that this other remain unharmed or even receive help, support, and relief. This end alone presses the stamp of moral worth on his action or omission (Schopenhauer 1841b, p. 212).

Thus, while egoistic actions are motivated by one's own well-being and woe, actions that are motivated by compassion exclusively are motivated by another's wellbeing and woe.

This, however, necessarily presupposes that I suffer along with his woe, feel his woe, as otherwise I would only mine, and therefore, I immediately will his wellbeing as, otherwise, I would only my own. However, this requires that I be identified with him in some way, i.e., that the complete distinction between me and the other, upon precisely which my egoism rests, to a certain degree be suspended (Ibid., 1841b, p. 212).

This demonstrates that, in order to encapsulate the meaning of the only incentive that Schopenhauer regards as valid for genuine morally actions, the English word "compassion" has to be understood more as a "suffering-with", as this would be the closest translation of Mitleid [Mit = with; Leid $=$ suffering] (Cartwright, 1988). It becomes obvious that his understanding of moral behavior is very closely related to the Christian command of 'love your neighbor as yourself'. However, if someone were to act following this guiding principle because it is a command (e.g., because someone is religious), it would again be without moral worth, because it derives not from one's compassion for another, but from the obeying of a principle or even a command. Here the same applies when Schopenhauer criticizes Kant's categorical imperative claiming to be a guideline for moral behavior: if one acts on the basis of a principle or command (e.g., because one has recognized that life is then easier, or one can prevent future personal woe) this act can never be moral, because, at least partially, the incentive of acting always contains elements that are related to one's own well-being and woe in this life (or, in case of a religious command, also after this life) and it is not exclusively based on compassion.

Only this compassion is the actual basis of all free justice and all genuine loving kindness. Only insofar as an action has originated from compassion does it have moral worth, and anything proceeding from any other motives has none (Ibid., 1841b, p. 213).

\section{Malice}

Besides egoism and compassion, Schopenhauer identifies a third incentive for human action: malice. ${ }^{1}$ Where compassion desires another's well-being, malice desires another's woe. Like "compassion, it is disinterested, but which makes another's pain its ultimate end" (Ibid., 1841b, p. 213), but Schopenhauer places a value on egoistic action that is different and distinct from that placed on malicious actions, "since all actions stemming from [... malice] are morally reprehensible, while [... egoism], in part, produces morally indifferent actions" (Ibid., 1841b, p. 214). Thus, both malice and egoism lack moral worth, but the former is bad, and the latter is neither good nor bad. Malice implies harming others. CSR and DM practices, on the other hand, aim, by definition, at doing good. Malice, therefore, does not need not to be discussed any further at this point.

\section{The Virtue of Justice and the Virtue of Loving Kindness}

"Every human action must trace back to one of these [three] incentives although two of these can also work in unity" (Ibid., 1841b, p. 214). For Schopenhauer, some actions express more compassion than others, just as some actions express more malice or egoism than others. As the universal maxim for actions of genuine moral worth, which thus stands as Schopenhauer's supreme principle of ethics, he postulates "harm no one; rather help everyone as much as you can" (Ibid., 1841b, p. 216).

The two clauses of this maxim attach corresponding actions which are different degrees of compassion, and therefore of moral worth. Schopenhauer identifies two

\footnotetext{
${ }^{1}$ Much later, and somewhat divorced from his considerations in "On the Basis of Morality", Schopenhauer does, in fact, mention a fourth, unnamed incentive for human actions "which desires one's own woe. Schopenhauer provided little description of this last incentive and he claimed in a letter that it does not possess moral value [... as it] only concerns actors themselves." Cartwright (2004). Historical Dictionary of Schopenhauer's Philosophy. Lanham: Scarecrow Press.
} 
classes of actions based on this maxim that he classifies as virtues: The virtue of justice and the virtue of loving kindness.

These virtues represent "two clearly separated degrees to which the suffering of another immediately becomes my motive, i.e., can determine me to do or not to do something" (Ibid., 1841b, p. 216). The virtue of justice represents the lower degree of compassion, "working against egoistic or malicious motives, it restraints me from causing another's suffering, from myself becoming the cause of another's pain, from giving rise to that which still does not exist" (Ibid., 1841b, p. 216). The virtue of justice keeps one from harming another for the purpose of gaining a personal advantage, or just from following malicious motivations. In terms of just actions "it is no way required that compassion actually be provoked in every single case, for it often would come too late; rather, from the knowledge achieved once and for all of the suffering which any unjust action necessarily brings to another, which is intensified by the feeling of the endurance of 'unjustice', i.e., of another's superior power, in noble temperaments the maxim "harm no one" arises" (Ibid., 1841b, p. 218) and becomes a principle. "For although principles and abstract cognition generally are in no way the fountainhead or the prime basis of morality, they are nevertheless indispensable for a moral course of life as the container, the réservoir, in which is stored the disposition which has sprung from the source of all morality" (Ibid., 1841b, p. 218).

The second virtue is the virtue of loving kindness. As a higher degree of compassion, it goes one step further, and "differentiates itself from the first degree [i.e. justice] by the positive character of the actions arising from it, since compassion does not just restrain me from injuring another, but even impels me to help him" (Ibid., 1841b, p. 229). As compassion, in general terms, means a concern for another's well-being and woe, the virtue of justice represents one's concern about another's woe only insofar and insomuch as one avoids being responsible for another's woe. The virtue of loving kindness, in addition to this, also includes a concern about woe experienced by another that has emerged unrelated to oneself, and it includes one's concern about another's well-being. Thus, actions based on the virtue of loving kindness, help others to reduce their woe and enhance their well-being. In contrast, actions which are rooted in the virtue of justice "only" keep one away from being the cause of another's woe. Nevertheless, both virtues render actions being based in them morally praiseworthy. However, although Schopenhauer utilizes the term "virtue" his code of ethics is not one of "virtue ethics" (such as the Aristotelian Nicomachean Ethics) which seeks to prescribe how humans should act in order to act in a morally "good" way. Neither are his maxims to be understood as some sort of "duty" motivating human actions. For Schopenhauer, every "ought simply has no sense and meaning except in relation to threatened punishment or promised reward" (Ibid., 1841b, p. 139). This would make obedience to it "self-interested, and hence, without moral worth" (Ibid., 1841b, p. 139). Thus, both the maxim and the two virtues that are inherent in it, are criteria for evaluating the moral worth of human actions. This reflects Schopenhauer's underlying assumption that ethics should not be framed "in a legislative-imperative form [...] as the philosopher in general must be content with an explanation and interpretation of that which is given" (Ibid., 1841b, pp. 136-137). For Schopenhauer, telling people what they morally ought to do, or what they should do, is unnecessary, since, if they are already disposed to do what is prescribed they will do it in any case or, if they are not so disposed, only the promise of reward or fear of punishment will compel them to act (Cartwright 1999, pp. 257-259).

Before evaluating the organizational motives for implementing these practices, it must be discussed in the next chapter how organizations can be regarded as moral agents.

\section{The Moral Status of Organizations}

The term "Corporate Social Responsibility" itself seems to imply the assumption that corporations are fully fledged moral agents (Klonoski 1991). The idea of 'responsibility' and related 'responsible behavior' points to an imperative morality being based on principles, commands, or other kinds of expectations about morally 'good' behavior. Thus, from a Schopenhauerian perspective 'responsibility' would have to be interpreted as the responsibility to act upon the basis of the principle "harm no one; rather help everyone as much as you can". In order to attach moral worth to actions based on this principle, from a Schopenhauerian perspective, the observance of this principle (or of the first part of it) would have to derive from compassion tangibly sensed in the present, or from compassion that was tangibly sensed in the past. Aside from principle-based acting, moral praiseworthiness or blameworthiness of actions can only be attached to actions if these actions spring from compassion or, (in the case of blameworthiness), from malice. Egoism, as a motive for acting, can be set aside from this perspective, since action based on this motive is morally neutral, and so is neither morally praiseworthy nor blameworthy. Thus, in Schopenhauerian terms, corporate moral agency can be defined as the capacity to act out of compassion or malice.

In this context an important question remains: can organizations, as such, act intentionally in such a way that compassion or malice can be the motives for their actions? This would be the precondition for attaching morality to their behavior. If organizations cannot be considered as 
moral agents, then it has to be asked whether there is someone else who can instead. The law, in most countries, treats organizations as legal persons, and, in doing so, it makes, for example, CSR or DM practices attributable to organizations. Thus, from a legal perspective, organizations are usually treated as being fully responsible, and therefore fully blameworthy or praiseworthy for their practices (Velasquez 2003). However, legal systems generally cannot be equalized with morality systems (Frenkel and Lurie 2001), and "rights and autonomy under the law are not identical with moral personhood" (Werhane 1985, p. 34). Thus, the question remains (Constantinescu and Kaptein 2014). To approach this question and to discuss the applicability of Schopenhauer's ethics, it is necessary to distinguish between an "organic view" and an "atomic view" of organizational responsibility (Wolf 1985).

\section{The Organic and the Atomic View of Organizational Responsibility}

\section{The Organic View from a Schopenhauerian Perspective}

One might argue that an organization is not merely the sum of its members. There might be a certain organizational structure or certain guiding principles, that provide at least some evidence for regarding organizations as "full-fledged irreducible moral agents" (Wolf 1985, p. 270). Wolf (1985) calls this the "Organic View of Organizations", and in a more exclusive perspective this view can also be called the "doctrine of un-redistributable corporate moral responsibility" (Garrett 1989). From this standpoint, "it is at least theoretically possible that an organization do something morally praiseworthy even though none of its members do anything praiseworthy" (Wolf 1985, p. 270). To attach moral agency to organizations, it is required that they act intentionally (Moore 1999, p. 330); from a Schopenhauerian perspective then, an analysis is required as to whether this organizational intention is based on compassion, egoism, or malice. It would have to be shown "that there is sense in saying that corporations and not just the people who work in them have reasons for doing what they do" (French 1984, p. 40).

French introduces the term "Corporation's Internal Decision Structure" and utilizes it for arguing that organizations are fully fledged moral agents: "Every corporation has an internal decision structure [that includes] (1) an organizational or responsibility flow chart that delineates stations and levels within the corporate power structure and (2) corporate decision recognition rule(s) (usually embedded in something called "corporation policy")" (French 1979, p. 212). For French (1979), these structures make corporations intentional entities, because, by dint of these structures, they can act intentionally, and therefore they have fully fledged moral agency. However, even if one were to accept that the "Corporation's Internal Decision Structures" make corporations "intentional systems" (French 1979), "it does not follow that all intentional systems are moral agents" (Werhane 1985, p. 38). Suggesting that French's line of argumentation is very questionable, Werhane states that the corporates "so-called intentions and their "actions" [derived from these intentions] are the collective result of decisions made by individual persons. The corporate is an eliminatable subject because without persons, corporate "actions" literally could not occur" (Werhane 1985, p. 39).

As outlined above, principle-based acting, as "just", and therefore morally praiseworthy, is possible in Schopenhauer's ethics. Thus, a moral perspective on organizations themselves could derive from the possibility that an organization has "subjected itself to recognizably moral constraints; it could have incorporated moral considerations and constraints into its decision-making procedure" (Wolf 1985 , p. 275), such as the principle "do not harm anyone" as part of their "Corporation's Internal Decision Structures" (French 1979). Nevertheless, the incentives for implementing these "moral" constraints would be the driving forces for certain individual persons in charge of the organization, who structured and shaped that organization; this would, therefore, at least question the moral worth of these organizational principles, at least in as far as the moral praiseworthiness would be attached to the organization itself.

If - in more concrete terms - 'moral' arguments are applied within organizations in such a way that an organization 'should care for its workers and it should treat them equally', or 'should protect the natural environment', these prescriptive commands could be interpreted as a "réservoir, in which is stored the disposition which has sprung from the source of all morality" (Schopenhauer 1841 b, p. 218). In this case, organizational initiatives that follow these principles could be interpreted as just, and thus they could have moral worth. The designation of the principles of, for example, treating every employee equally, would then derive from compassion and from the motivation to act justly. The implementation of a guiding and binding principle would be an attempt to ensure that organizational members act justly, and to prevent them from letting egoistic or malicious motive lead them into counteracting the intended directions of the principles. The moral worth of acting beyond these principles can then only be ascribed to the person who has established these principles, and not to the organization itself.

A scenario is imaginable in which DM or CSR initiatives were developed by a compassionate individual, became institutionalized as policies, and are subsequently 
applied or executed by persons who do not have such compassion themselves. These persons might be guided by the fear of punishment that might be inherent in a violation of these policies, or exhibiting opposition to them. Nevertheless, these actions themselves are rooted (in the past) in compassion, although moral worth is not attached through them to those who execute them (in the present). However, in this case it is not the organization itself, as an organizational actor, who can be seen as responsible for the implementation of the principles, as the implementation can be traced back to certain persons in charge who established these guidelines out of compassion, or out of the motivation to act justly.

Several studies try to identify standards or ideals for morally praiseworthy behavior of organizations. Examples for such ideals are DeGeorge's (1993) concept of having a"moral minimum" governing how and what companies should act and do, and, further to this, defining behavioral standards that exceed this minimum which can characterize "companies of integrity", i.e., companies who act in a morally praiseworthy fashion (DeGeorge 1993). Examples would also include any kind of definition of unethical behavior (Kaptein 2008a, b), any kind of "golden rule" of ethical behavior and moral reasoning (Velasquez 2002), any kind of virtue ethics (Solomon 1992), and any kind of "guiding" prescriptive responsibility that derives from ascribing to corporations the status of being corporate citizens (Crane and Matten 2010), or from an understanding of "social contracts" that bind economic systems and corporations into communities (Donaldson and Dunfee 1999). However, any kind of moral ideal for the organizational actions which exceeds the principle "Harm no one; rather help as much as you can" would not apply under Schopenhauerian ethics. Even then, the moral praiseworthiness of these actions would more properly be attached to the individuals within these organizations who have implemented these standards or policies.

Furthermore, it is highly questionable that every organization has, as French (1979, p. 212) would have it, a clear responsibility flow chart and a binding and comprehensive corporation policy. Moreover, in a case of an organization genuinely having both, it is doubtful that organizational decisions (i.e., decisions of persons in charge within the organizations) always follow the predefined decision track, and that they always comply with the policies. This question is mainly discussed in a context of legal morality, questioning whether organizations as such, or only organizational members can be prosecuted and punished for "organizational" actions by state justice. As already outlined above, Schopenhauer describes the sole purpose of states and their laws as "to protect individuals from one another and the whole from external enemies" (Schopenhauer $1841 \mathrm{~b}$, p. 221). This is not a question of morality, but only a question of legally taming people's egoisms (Jordan 2009).

Nevertheless, one stream of research on corporate moral agency builds on French's (1979) postulation that organizations have internal decision structures, organizational guidelines and rules making them, as a cohesive unit, act like humans. Based on this assumption, Goodpaster and Matthews (1982) attach moral agency to corporations, claiming that organizations can have a corporate conscience. They argue that one can project the idea of humans having a "conscience" onto organizations as well. This "corporate conscience" can provide some kind of moral guidance to the organization for acting in a morally "good" way, and, just as with humans, it can make organizations, as units, act responsibly. By stipulating "responsible" behavior as an outcome of conscientious acting, they think that the moral responsibility of individuals is also projectable onto corporations, giving them a guiding conscience (Goodpaster and Matthews 1982, p. 135). One could translate this approach into the Schopenhauerian perspective on moral agency and regard this conscience as a moral instance that provides organizations with the capacity to feel compassion. As a further consequence, this conscience could then lead to praiseworthy organizational actions, or it could prevent organizations from acting in a blameworthy manner. However, besides the dubiousness nature of this somewhat fragile line of argumentation, partially equalizing acting humans with organizations, the whole concept of "conscience" (and thus also of a "corporate conscience"), would be highly questionable from a Schopenhauerian perspective. Although, he assumes "that actions of moral worth leave with us [...] a certain contentment that is called the approval of conscience" (Schopenhauer 1841b, p. 209), this effect of morally "good" actions does not enable the conscience guiding these actions; quite the contrary: Many a one "would be amazed if he were to realize of what his conscience, which seems to him to be so imposing, is actually composed: approximately $1 / 5$ fear of humans, $1 / 5$ fear of the gods, $1 / 5$ prejudice, 1/5 vanity, and 1/5 habit" (Schopenhauer 1841b, p. 199). Thus, as the concept of having a conscience is, for Schopenhauer, a completely irrelevant category for moral action, it follows that the idea of a "corporate conscience" as a basis for morally worthy actions becomes null and void.

Another argument, however, for doubting the possibility that organizations could act in a morally "good" or "bad" fashion from a Schopenhauerian perspective on morality is that "organizations do not have any emotional capacities. They lack the unified consciousnesses necessary for feeling" (Wolf 1985, p. 279). Thus, organizations can hardly feel compassion (Simpson et al. 2014; Solomon 1998) or malice, and therefore they are incapable of developing a motivation that makes them act in a morally "good" or "bad" way, that would render them blameworthy or praiseworthy in terms of their actions. Furthermore, it is 
questionable whether an organization can act on the basis of egoism. In capitalistic societies 'egoism' might be seen as an accepted given for profit-driven organizations as part of the Darwinian everyday battle on the global market (Lynch 2009) called 'competition'. In this context, it would be worth discussing, whether, in capitalistic societies, private companies are something akin to the incorporation of egoism into a non-personal body or entity (Mander 1992), and thus, their behavior or acting is a priori and has no moral worth. In this case, egoism cannot to be seen as an emotional organizational state; instead it can be interpreted as part of the "corporate DNA" (Mander 1992, p. 58) that constitutes the motivational basis for organizational acting. Nevertheless, even in these cases it is the individuals who act within the organizations.

\section{The Atomic View from a Schopenhauerian Perspective}

It has been shown that there is relatively little incident for assuming that organizations, as units, have moral agency. However, individuals definitely do so. Thus, the individuals acting within organizations have moral agency. This leads to the "Atomic View of Organizational Responsibility". The Atomic View argues that "organizations are, after all, composed of individuals" (Wolf 1985, p. 268) and "whenever an organization is responsible for an action, one can always trace back the responsibility to some of the persons within it" (Wolf 1985 , p. 269). This argument is fundamentally in line with the aforementioned position of Werhane (1985, p. 39), although she claims "that corporations are collective secondary moral agents" (Werhane 1989, p. 821). She derives this agency from the necessity of having someone who is morally responsible, in the case of organizational policies or practices which are not, or are no longer, traceable to distinct individuals. "But this is not to excuse individuals since they are the [creator and] perpetuators of corporate activity in the first place" (Werhane 1989, p. 822). From a Schopenhauerian perspective, an action or policy that cannot be traced back to an individual simply cannot have any moral worth - there is no necessity per se to attach a moral worth to every action. In fact, almost the reverse applies: a moral worth can only be attached to actions that can be traced back.

In the case of implementing DM or CSR activities, it is therefore necessary to trace the process back to the incentives of the individuals that were responsible for the implementation within the organizations to find evidence for any kind of morality in these actions. This morality can then only be attached to these concrete persons, not to an organization. Since for Schopenhauer the omission of an action is an action as well, that is also rooted in one's egoism, compassion or malice, it follows that the motives of the people within the organization that deliberately did not oppose the implementation, although they had the power to do so, can be morally "good" or otherwise. Thus, besides the organizational members "in the first row" that pushed forward the implementation of DM or CSR initiatives, there might be a broad "second row" of persons that deliberately did (or did not) put obstacles in the way of the implementation process, or that even took some obstacles away, unknown to others. These persons also have motives for their actions. Thus, their actions too can be morally evaluated from a Schopenhauerian perspective. However, in an Atomic View of organizations the moral value of the organizational actions can only be derived from individual's motives.

To summarize, from a Schopenhauerian perspective, corporate moral agency would inevitably have to be tied to a corporation's capacity to act out of compassion or malice. However, organizations do not meet the precondition of developing these incentives for acting because they are not capable of feeling in general. Thus, they are neither capable of suffering or feeling "well" in and of themselves, nor of feeling the suffering or well-being of others. Therefore, they cannot make their own suffering and wellbeing, or that of others, their motivation for acting, and thus they lack the capacity to act out of compassion or malice. It follows, therefore, that from a Schopenhauerian standpoint, there is no evidence for attaching moral agency to organizations themselves, because they are not capable of developing incentives for their actions that are valid for moral considerations. These incentives can be exclusively held by individuals within organizations, making their actions morally 'good' or otherwise. In the next chapter, different types of individual motivations and general argumentative considerations for implementing DM or CSR initiatives will be outlined and discussed in the light of Schopenhauer's ethic.

\section{Motivations for Implementing CSR and DM}

As this article focuses on the reasons as to why organizations and companies implement CSR or DM initiatives, in order to evaluate their moral worth, a closer look at the main arguments that are often applied for legitimizing the implementation of these initiatives is necessary.

Most literature examining the reasons why organizations implement or should implement CSR or DM initiatives tries to prove or to question a kind of business case of these initiatives (Carroll and Shabana 2010; Weber 2008). There is a huge amount of literature on the interrelation of CSR initiatives and organizations' reputations (Branco and Rodrigues 2006; Fombrun 2005). A positive reputation is mostly seen as crucial for making an organization's interaction with its stakeholders most profitable for the organization (McGuire et al. 1988; Morsing and Schultz 2006), 
especially for multinational companies (Chapple and Moon 2005; Hah and Freeman 2013). Lines of argumentation are, for example, that a positive reputation attracts more, and better, employees (Jones et al. 2014); that it contributes to attracting new customers and to retaining established ones (Luo and Bhattacharya 2006; Ven 2008); that it eases the way in which states order goods or services; or that it makes suppliers provide better conditions (McWilliams and Siegel 2001). Another strand of research shows that the personal values of those individuals in charge within the organizations are a crucial criterion for organizations which are implementing CSR initiatives (Chin et al. 2013; Cui et al. 2014; Hemingway and Maclagan 2004). There is another (smaller) body of literature that elaborates on the different kinds of moral reasons as to why organizations implement or should implement CSR initiatives (Frederiksen 2010).

As with CSR, there also exists a huge amount of literature on business case perspectives on DM. However, as the main target group of organizational DM initiatives is usually the organizations' own diverse workforces (instead of the general public, as is usually the case with CSR initiatives) there are more lines of argumentation for a business case of DM, besides ameliorating organizations' reputations (Martín-Alcázar et al. 2013). One field of research analyzes how far a diverse workforce itself is already a benefit for the organization, e.g., because it is making it more creative and innovative, more understanding and attractive for diverse customers, or less vulnerable to external changes (Robinson and Dechant 1997). This stream of research economically legitimizes the implementation of DM initiatives, aiming at creating a diverse workforce. Another field of research assumes a diverse composition of the workforce as a given, and focuses on the best way of managing this diversity, and how to receive the optimal outcome of it in terms of the organization's performance (Cox and Blake 1991). As DM is closely related to the idea of equality and equal opportunities [partially also to the idea of equality of outcome (Phillips 2004)], there is also a body of literature on evaluating and conceptualizing DM on the basis of imperative morality that assumes equality to be morally 'good' (Anderson 1999).

Nevertheless, there is still an intense call for more studies on the business case of CSR and DM. There seems to be a special desire for studies that give organizations concrete numbers in a way that predicts how many Euros one gets back for each Euro one 'invests' in CSR or DM initiatives (Heitner et al. 2013; Valor 2005). This might be due to the still predominant assumption within the private sector that the main goal of any corporate action is to maximize the shareholder value; from this perspective, every organizational initiative is constrained by the fact that it must pay off, in order to lend it legitimacy; in these terms reaching equality would then have no self-worth, since revenue would cease to be generated (Barnea and Rubin 2010). In line with the argument that CSR and DM initiatives ameliorate organizational reputation, other stakeholders' interests can also be subsumed under this line of maximizing profit and company value (e.g. Roberson and Park 2007).

It now remains to be discussed who, from a Schopenhauerian perspective, would have an incentive (and, indeed, what manner of incentive), to implement CSR or DM initiatives, and what would then follow from this decision in terms of their moral praiseworthiness or blameworthiness. As outlined in the chapter above, it is indicative that moral agency could only be attached to individuals acting within organizations, and not to organizations themselves. From a Schopenhauerian perspective, organizations, although they might be capable of acting intentionally (and this is a highly controversial issue in literature (see e.g., Velasquez 2003), are not capable of behaving in a morally good or bad way. Thus, in the following chapter the morality of individual behavior within organizations will be discussed from a Schopenhauerian perspective.

\section{The Morality of Individual Behavior Within Organizations in Terms of CSR and DM}

Having discussed the potential morality of organization themselves, in the process of implementing CSR or DM initiatives, the individuals that work within these organizations should be looked at more closely. Individuals are definitely moral agents, and thus they have the potential to act in a morally 'good' way. The question in the context of organizational CSR and DM initiatives is what the motives of individuals are in initiating, supporting, or, at least, not opposing the implementation of these initiatives.

\section{Contextual Factors and "Ethical" Decision Making}

Before discussing the significance of compassion as a potential motive, the role of contextual pressure-and organizational context in general-has to be considered as an active element in the process of individual decision making. Treviño et al. (2006) indentify different organizational factors that influence every process and outcome of, as they term it, an "individual's ethical decision-making", such as a given organization's ethical (sub-)climates and culture, ethical leadership, linguistic practices applied within organizations, and organizational systems of reward and punishment (Treviño et al. 2006). Moreover, the "ethical" behavior of individuals can be influenced by potentially conflicting expectations and the demands of different 
stakeholders and also colleagues (Davis and Frederick 1984; Kaptein and Wempe 2002; Treviño and Weaver 2003). It is true that contextual factors might influence individual's decision making. However, within a Schopenhauerian framework, this does not make any difference, since these contextual factors do not hinder the individual in terms of allowing either compassion or malice to be the guiding incentives for acting.

From a Schopenhauerian perspective, every decision that might affect the well-being of another person or people can become a "moral" decision. This is the case when this other person's well-being is the criterion or the motive for the decision. There are very few conceivable decisions that could in no way be related to the well-being of others, regardless of whether one were to wish to affect it in a negative or positive way. Even, say, the decision of whether to have coffee or tea for breakfast, could, at least in theoretical terms, become a moral decision, if being made out of considerations that are related to the well-being of coffee or tea farmers, or the livelihood of those persons selling the coffee or tea. Decisions that would seldom become moral decisions would include, for example, technical decisions, e.g., about positioning and connecting different machines in a production line. Thus, most decisions that lead to an action can be motivated by compassion or not, and so most decisions can bear moral worth or not. Thus, from a Schopenhauerian perspective, considering "moral decision" as a type of decision that is distinct from other kinds of decision is more or less only a distinction in terms of the underlying motivations for those decisions. A distinction between moral and non-moral decisions using their "field", subject, or topic can hardly be done. Thus, the category of "ethical decisions" or "ethical decision making" is not an adequate framing for a Schopenhauerian approach.

\section{Individuals' Estimations Toward Business Case Considerations}

What makes a difference in evaluating individuals' motives in terms of their moral value is whether one believes the aforementioned assumption about CSR or DM strengthening organizational competitiveness and ameliorating organizations' reputations. In the case where one does indeed believe this, support of these initiatives might be due to an individual's career aspirations. The individual might, in this case, aim at strengthening the organization, in order to thereby achieve a personal success that might help him or her for future promotions. Against this background, one might also push forward these initiatives in order to secure one's own job in a more competitive organization. As the "necessity of a good name" exists for the individual as well as for the organization the motive for supporting or initiating these initiatives may also derive from societal or legal pressure. This pressure can affect the individual because of his or her position within the organization (e.g., being a 'good' human resource manager or boss), regardless of whether one believes the business case argumentation. All of these incentives for supporting CSR or DM initiatives contain elements of individuals' own well-being and woe, and thus, are, at least partially egoistic and therefore without genuine moral worth.

It might often be that actions are motivated by more than one intention, e.g., by egoism and by compassion, or by malice and by compassion, but from a Schopenhauerian perspective these actions then have no moral worth. $\mathrm{He}$ clearly states "that only another's distress and no other consideration must be my motive if my action is to have moral worth" (Schopenhauer 1841b, p. 230).

There are two conceivable cases in which individuals initiate or support the implementation of CSR or DM initiatives motivated by compassion, but from a Schopenhauerian perspective only one of these can clearly be ascribed genuine moral worth.

\section{Organizational Citizenship Behavior}

Schopenhauer argues that in order to feel real compassion for another, one has to identify oneself with this other, and to feel his or her suffering as one's own, not within oneself, but in the other person (Cartwright 2012). Identifying in this context means that "the barrier between I and Not-I has been suspended: only then will there be the opportunity immediately to take on as my own another's need, his distress, his suffering" (Schopenhauer 1841b, p. 231). There is one concept in business and management studies that closely correspond to this approach to compassion: organizational citizenship behavior (OCB). Organ (1988) describes this phenomenon as the "good soldier syndrome", which describes the different propensities of employees to voluntarily assist or help colleagues, and to promote the competitiveness and economic well-being of their employing organization without expecting any kind of direct or indirect reward or compensation for their conduct. [It should be noted in this light that the concept of OCB should not be confused with corporate citizenship, although corporate citizenship might have an impact on the OCB of employees (Lin et al. 2010)]. Employees apply OCB when their level of identification with the organization for which they work is that high, that their main incentive for acting is concern about the well-being and woe of the organization (Smith et al. 1983). The entity one senses compassion with in this case is not another individual, but an organization. This raises the question of whether organizations can be equally ranged with individuals (and animals) as entities for which one can have compassion. If so, from a Schopenhauerian perspective, acting based on OCB would 
only lack moral worth if the organization's well-being is perceived by the actor as a means to promote the wellbeing of the actor him or herself. However, individuals who apply this behavior necessarily have to be a part (or a member) of the organization to which they are applying this behavior. Thus, the organization cannot clearly be distinguished from oneself as "the other" for whom one has compassion. It remains, at the very least, controversial, as to whether acting in favor of organizational well-being and woe might not at least partially be inevitably a simultaneous egoistic acting in favor of one's individual well-being and woe. Therefore, aside from further debate as to whether an organization can be an object of compassion, it is difficult to assign moral worth to OCB.

\section{Genuine Compassion with Individuals or Animals}

In terms of morally good CSR or DM initiatives, genuine moral worth can more clearly be found on the level of individuals having compassion with other individuals. It is definitely conceivable that an individual feels compassion, for example with the factory workers in an Asian country that produce goods for the company a given individual may be working for. In this case, the individual feels the suffering of these people because of the bad conditions they have to work in, as his or her own suffering. This might motivate him or her to initiate or support organizational CSR initiatives that aim to ameliorate their working conditions and relieve their suffering that is sensed as one's own suffering. Schopenhauer explicitly includes animals in his moral philosophy, arguing that having compassion with their sufferings also can lead to the same moral worthiness of an individual's actions, as would be the case with compassion shown for humans. Thus, another example could be the support of corporate initiatives aiming to ameliorate animal welfare.

Besides these CSR initiatives, the same applies to DM. Individuals might sense as their own suffering the suffering of, for example, female, homosexual, foreign, or black colleagues because of everyday workplace discrimination or marginalization, although the individual does not share the same manifestations of the respective dimension of diversity, or the individual does share it but does not feel the marginalization directly directed at him or herself. It might be more probable that an individual can identify with a suffering person who is suffering for precisely the same reason that the individual has suffered him or herself, either currently, or in the past (e.g., because that individual is also a woman or one is also gay). Nevertheless, it is easily conceivable that one could support or initiate DM initiatives without having an incentive that is related to one's personal suffering, and thus is only rooted in the motive of reducing other's woe or enhancing their well-being. In this case, it is not important to differentiate whether this compassion is only a selective compassion or whether it is activated as part of one's virtues of aiming at justice (including principlebased acting) or having embodied loving kindness.

\section{Compassion and Business Case Rhetoric}

As compassion is a motive of action that is not totally compatible with organizational discourses on profitability, one might choose to utilize a business case argumentation to initiate the implementation process or to support it, regardless of whether one believes it or not. In the case of one not believing in the positive economic consequences of these initiatives, the exploitation of business case arguments might be seen as a lie, but this lie still can be morally acceptable. Schopenhauer does not classify lying as morally reprehensible in general. He explicitly sees cases in which one has the "right to tell lies" (Schopenhauer 1841b, p. 159), for example if the lie is "the legitimate means of defense against unauthorized inquisitiveness, whose motive is hardly ever benevolent" (Schopenhauer 1841b, p. 159).

Schopenhauer's formula to measure the quantity of injustice can show that leading stakeholders to believe in business case lines of argumentation does not necessarily take away the moral worth of implementing CSR or DM activities that derive from this starting point: "The amount of injustice in my conduct is equal to that of the evil I thereby inflict on another divided by the amount of advantage I thereby obtain" (Schopenhauer 1841b, p. 155). Thus, if the incentives motivating the individual's acting in these cases are solely based in the well-being and woe of those people who are the target groups of the CSR and DM initiatives, the question remains as to who else might be affected negatively by these actions. In the case of these actions being economically harmful to organizations profitability, a potential harm would emerge for the owners of the organization, e.g., the shareholders, as they would get a lower return on their investments. Particularly in the field of DM, many activities aimed at including a diverse workforce are mainly of symbolic nature without consuming huge budgets (Gilbert et al. 1999). CSR initiatives, for example, can include a restructuring of internal supply chains that might bring with it higher purchase prices, but also here, just as in the field of DM, studies that doubt the business case line of argumentation mostly show that they might yield no positive economical consequences, but will also yield no negative ones (Carroll and Shabana 2010; Herring 2009). Positive economic consequences of CSR and DM initiatives are often mediated by their positive impact on the reputation of organizations. A good reputation could then, for example, make organizations more attractive to customers or talented employees (Lii and Lee 2012; Roberson and Park 2007). This kind of "win- 
win situation" would not call the potential moral worth of these initiatives into question. However, this positive interrelation does not necessarily occur. Johnston and Malina (2008), for example, show that there is no positive correlation between the implementation of sexual orientation DM and the firm value of an organization-but they also do not find a negative correlation (Johnston and Malina 2008). Thus, some DM or CSR initiatives might not bring any kind of return on investment. An organization might, for example, support certain CSR initiatives in the region it is operating in without overtly drawing attention to this, or advertising it in any way. Thus, it might be that no reputation effect emerges out of it. This gives the numerator of Schopenhauer's formula a value of zero. Thus, a knowingly false stressing of the profitability of CSR and DM activities does not harm the moral worth of the implementation of these initiatives, so long as it only derives from compassion, and the initiatives are "only" "neutral" and not harmful in economic terms. Thus, derived from the level of individuals acting within organizations, it is possible to classify CSR or DM initiatives as morally good. In order to uncover their moral 'goodness', the business case rhetoric utilized by compassionate organizational actors has to be unmasked and identified as a means to the end of overcoming organizational resistance, regardless of whether this rhetoric is believed to be true or not.

\section{Summary and Conclusion}

It has been shown that, from a Schopenhauerian perspective, CSR and DM initiatives have a genuine moral worth only in so far as individuals who have initiated or supported their implementation are exclusively motivated by compassion. In referring to Schopenhauer's ethics, this article has developed a perspective on the moral evaluation of organizational initiatives that, as the sole criterion for the evaluation of their moral value, is based on the motives for their implementation, instead of the initiatives themselves. CSR and DM initiatives most commonly tend to be evaluated through different kinds of prescriptive moralities (partially only implicitly), that focus on the initiatives themselves in order to attach moral value to them [in the case of applying a Kantian perspective, their moral worth depends on whether they are implemented out of "duty" (Evan and Freeman 1988; Guyer 2012)]. Diversity management is then equalized with equality and equal opportunity considerations, whereby equality is then assumed to be a criterion of morally 'good' action. CSR, against this background, stands for itself, as the concept of 'social' behavior and 'responsible' behavior toward humans (and the environment) can easily be considered as criteria for moral 'goodness'. In denying any kind of prescriptive morality, a Schopenhauerian view contrasts these widely held views on DM and CSR, and offers a new perspective on the morality of CSR and DM. By placing a special emphasis on individuals' incentives in the process of implementing these initiatives, a new stream of research can be opened up. Hitherto, the role of individuals in CSR and DM research is considered merely peripheral. It is mostly taken for granted that these initiatives are, in any case, morally 'good'. Taking into account that the diffusion of these seemingly 'good' initiatives is not solely due to organizational selflessness, a huge stream of research into the business case of CSR and DM has emerged, analyzing the economic impact of these initiatives (Carroll and Shabana 2010; Robinson and Dechant 1997). Presupposing that there is a business case seems to take away the decision for implementing CSR and DM from the individual level, and transfers it to an organizational level, as 'being bottom-line' seems to be the modus operandi of every (profit-oriented) organization. Persons in charge of the implementation within the organizations, in this perspective, lose their individual motivation, and become performing agents of an organizational profit-oriented principle. This approach ignores the individuals' maneuvering room in the process of implementation that might be used for individual purposes. The Schopenhauerian perspective allows the integration of this individual perspective into the discourse on the morality of CSR and DM. Individuals within organizations might be guided by genuine compassion when initiating or supporting the implementation of these actions. These individuals might also be aware that compassion is not an adequate argument for convincing profit-oriented stakeholders, and this might be a reason why these individuals stress the narrative of a business case. In this context, it is conceivable that managers push forward, for example, DM initiatives in their companies from personal compassion. However, to the outside world, they might represent the narrative of the business case of DM, being fully aware that the implementation would otherwise have less support from certain stakeholders. This perspective broadens the discourse on business case perspectives on DM and CSR by integrating the organizational actors and their motivation for referring to business case considerations. In leaving open the possibility of merely utilizing the business case line of argumentation for a purpose that roots in actual fact in one's sensed compassion, a moral perspective is added to this discourse.

This Schopenhauerian perspective furthermore broadens the relatively new discourse on compassion that is mainly located in the field of positive organizational scholarship (POS). "POS is concerned primarily with the study of especially positive outcomes, processes, and attributes of organizations and their members" (Cameron et al. 2003, p. 5). In this context, compassion can be seen as both a positive attribute of organizational members, and a positive outcome of organizational processes. In the broadest sense, 
POS emphasizes its economic impact including "the happy side effect of enhancing profits" (Caza and Carroll 2012, p. 973). Thus, the discourse on organizational compassion, seen as something "expressed by managers towards employees [... or] between employees within organizations" (Simpson et al. 2014, p. 7), acquires a new ethical facet in addition to its psychological and economic side.

As, from a Schopenhauerian perspective, compassion needs an identification by the one who feels compassion with the one who is compassionated, this approach opens up another new stream of future research. Genuine compassion, on the one hand, can be a boundless compassion that is felt with every human-Schopenhauer calls this the virtue of loving kindness. As a "boundless compassion" (Fox 2006) this loving kindness does not make a difference between different humans, and CSR or DM approaches that are motivated by this loving kindness would aim at being as comprehensive as possible. Diversity management, then, would not limit itself to only few dimensions of diversity, such as gender or ethnicity. CSR initiatives would also try to reach as many humans, as possible and they would only be restricted by the organization's monetary budget. However, this boundlessness of organizational DM or CSR activities is, in practice, very rarely found in organizations, especially in profit-oriented organizations. Genuine compassion, however, can also be sensed for concrete persons with whom one identifies. Here the question arises as to what makes people identify with one another. Why does one identify with one person, and eliminate the difference between oneself and him or her, but the same person does not identify with another person? What, then, is the basis of people feeling compassion for certain other people? In terms of DM it might be the case that if one has experienced discrimination and marginalization because of a demographic one represents (e.g., because of being a woman or being gay), it makes it easier to identify with others who are suffering the same suffering one has experienced before. Thus, gay individuals might tend to be more compassionate toward gay persons, and sense their suffering more easily as their own suffering; the same could hold true for women, or people of a certain religion, etc. However, if this is the case, this might lead to variously shaped approaches to DM with different emphases, because of different individuals being in charge of it. Until now, this individual factor has mostly been ignored in research on DM and CSR, and so individual compassion could be a starting point for a new direction of research in this area. Future research can examine more closely the conditions and reasons as to why one individual identifies with another and what the consequences of this could be for the shape of corporate CSR and DM initiatives, or any other area of organizational action that might be judged on its potentially 'moral' content.

\section{References}

Anderson, E. S. (1999). What is the point of equality? Ethics, 109(2), 287-337.

Babiak, K., \& Trendafilova, S. (2011). CSR and environmental responsibility: Motives and pressures to adopt green management practices. Corporate Social Responsibility and Environmental Management, 18(1), 11-24.

Barnea, A., \& Rubin, A. (2010). Corporate social responsibility as a conflict between shareholders. Journal of Business Ethics, 97(1), $71-86$.

Branco, M. C., \& Rodrigues, L. L. (2006). Corporate social responsibility and resource-based perspectives. Journal of Business Ethics, 69(2), 111-132.

Cameron, K., Dutton, J., \& Quinn, R. E. (2003). Positive organizational scholarship: Foundations of a new discipline. San Francisco: Berrett-Koehler.

Carroll, A. B. (1998). The four faces of corporate citizenship. Business and Society Review, 100-101(1), 1-7.

Carroll, A. B. (1999). Corporate social responsibility: Evolution of a definitional construct. Business and Society, 38(3), 268-295.

Carroll, A. B., \& Shabana, K. M. (2010). The business case for corporate social responsibility: A review of concepts, research and practice. International Journal of Management Reviews, 12(1), 85-105.

Cartwright, D. E. (1988). Schopenhauer's compassion and Nietzsche's pity. Schopenhauer Jahrbuch, 69, 557-567.

Cartwright, D. E. (1999). Schopenhauer's narrower sense of morality. In C. Janaway (Ed.), The Cambridge companion to schopenhauer (pp. 252-292). Cambridge: Cambridge University Press.

Cartwright, D. E. (2004). Historical dictionary of Schopenhauer's philosophy. Lanham: Scarecrow Press.

Cartwright, D. E. (2008). Compassion and solidarity with sufferers: The metaphysics of mitleid. European Journal of Philosophy, 16(2), 292-310.

Cartwright, D. E. (2012). Schopenhauer on the value of compassion. In B. Vandenbeele (Ed.), A companion to schopenhauer (pp. 249-265). Malden and Oxford: Wiley-Blackwell.

Caza, A., \& Carroll, B. (2012). Critical theory and positive organizational scholarship. In K. S. Cameron \& J. P. Schneider (Eds.), The Oxford handbook of positive organizational scholarship (pp. 965-978). New York: Oxford University Press.

Chapple, W., \& Moon, J. (2005). Corporate social responsibility (CSR) in Asia: A seven-country study of CSR web site reporting. Business and Society, 44(4), 415-441.

Chin, M. K., Hambrick, D. C., \& Treviño, L. K. (2013). Political ideologies of CEOs: The influence of executives' values on corporate social responsibility. Administrative Science Quarterly, 58(2), 197-232.

Constantinescu, M., \& Kaptein, M. (2014). Mutually enhancing responsibility: A theoretical exploration of the interaction mechanisms between individual and corporate moral responsibility. Journal of Business Ethics, 1-15.

Coupland, C. (2006). Corporate social and environmental responsibility in web-based reports: Currency in the banking sector? Critical Perspectives on Accounting, 17(7), 865-881.

Cox, T. H., \& Blake, S. (1991). Managing cultural diversity: Implications for organizational competitiveness. The Executive, 5(3), 45-56.

Crane, A., \& Matten, D. (2010). Business ethics: Managing corporate citizenship and sustainability in the age of globalization. Oxford: Oxford University Press.

Cui, J., Jo, H., \& Velasquez, M. (2014). The influence of christian religiosity on managerial decisions concerning the environment. Journal of Business Ethics, 1-29. 
Dahlsrud, A. (2008). How corporate social responsibility is defined: An analysis of 37 definitions. Corporate Social Responsibility and Environmental Management, 15(1), 1-13.

Danilovic, M., Hensbergen, M., Hoveskog, M., \& Zadayannaya, L. (2013). Exploring diffusion and dynamics of corporate social responsibility. Corporate Social Responsibility and Environmental Management, n/a-n/a.

Dass, P., \& Parker, B. (1999). Strategies for managing human resource diversity: From resistance to learning. The Academy of Management Executive (1993-2005), 13(2), 68-80.

Davis, K., \& Frederick, W. C. (1984). Business and society: Management, public policy, ethics. New York: McGraw-Hill.

DeGeorge, R. T. (1993). Competing with integrity in international business. New York: Oxford University Press.

Demuijnck, G. (2014). Universal values and virtues in management versus cross-cultural moral relativism: An educational strategy to clear the ground for business ethics. Journal of Business Ethics, $1-19$.

Dierksmeier, C. (2013). Kant on virtue. Journal of Business Ethics, 113(4), 597-609.

Donaldson, T., \& Dunfee, T. W. (1999). Ties that bind: A social contracts approach to business ethics. Boston: Harvard Business Press.

Evan, W. M., \& Freeman, R. E. (1988). A Stakeholder theory of the modern corporation: Kantian capitalism. In T. L. Beauchamp \& N. Bowie (Eds.), Ethical theory and business (pp. 75-84). Englewood Cliffs: Prentice Hall.

Fombrun, C. J. (2005). Building corporate reputation through CSR initiatives: Evolving standards. Corporate Reputation Review, $8(1), 7-11$.

Fox, M. A. (2006). "Boundless Compassion": The contemporary relevance of Schopenhauer's ethics. The European Legacy, 11(4), 369-387.

Frederiksen, C. S. (2010). The relation between policies concerning corporate social responsibility (CSR) and philosophical moral theories-An empirical investigation. Journal of Business Ethics, 93(3), 357-371.

French, P. A. (1979). The corporation as a moral person. American Philosophical Quarterly, 16(3), 207-215.

French, P. A. (1984). Collective and corporate responsibility. New York: Columbia University Press.

Frenkel, D. A., \& Lurie, Y. (2001). Culpability of corporations-legal and ethical perspectives. Crime Law Quaterly, 45, 465-487.

Garrett, J. (1989). Unredistributable corporate moral responsibility. Journal of Business Ethics, 8(7), 535-545.

Garriga, E., \& Melé, D. (2004). Corporate social responsibility theories: Mapping the territory. Journal of Business Ethics, 53(1-2), 51-71.

Gilbert, J., Stead, B., \& Ivancevich, J. (1999). Diversity management: A new organizational paradigm. Journal of Business Ethics, 21(1), 61-76.

Goodpaster, K. E. (1983). The concept of corporate responsibility. Journal of Business Ethics, 2(1), 1-22.

Goodpaster, K. E., \& Matthews, J. B. (1982). Can a corporation have a conscience. Harvard Business Review, 60(1), 132-141.

Gotsis, G., \& Kortezi, Z. (2013). Ethical paradigms as potential foundations of diversity management initiatives in business organizations. Journal of Organizational Change Management, 26(6), 948-976.

Graafland, J. J., Eijffinger, S. C. W., \& Smid, H. (2004). Benchmarking of corporate social responsibility: Methodological problems and robustness. Journal of Business Ethics, 53(1-2), $137-152$.

Grosser, K., \& Moon, J. (2008). Developments in company reporting on workplace gender equality?: A corporate social responsibility perspective. Accounting Forum, 32(3), 179-198.
Guyer, P. (2012). Schopenhauer, Kant and compassion. Kantian Review, 17(03), 403-429.

Hah, K., \& Freeman, S. (2013). Multinational enterprise subsidiaries and their CSR: A conceptual framework of the management of CSR in smaller emerging economies. Journal of Business Ethics, $1-12$.

Heitner, K. L., Kahn, A. E., \& Sherman, K. C. (2013). Building consensus on defining success of diversity work in organizations. Consulting Psychology Journal: Practice and Research, 65(1), 58-73.

Hemingway, C., \& Maclagan, P. (2004). Managers' personal values as drivers of corporate social responsibility. Journal of Business Ethics, 50(1), 33-44.

Herring, C. (2009). Does diversity pay?: Race, gender, and the business case for diversity. American Sociological Review, 74(2), 208-224.

Holton, V. (2005). Diversity reporting: How European business is reporting on diversity and equal opportunities. Women in Management Review, 20(1), 72-77.

Idowu, S. O., \& Towler, B. A. (2004). A comparative study of the contents of corporate social responsibility reports of UK companies. Management of Environmental Quality: An International Journal, 15(4), 420-437.

Johnston, D., \& Malina, M. A. (2008). Managing sexual orientation diversity: The impact on firm value. Group and Organization Management, 33(5), 602-625.

Jones, K. P., King, E. B., Nelson, J., Geller, D. S., \& Bowes-Sperry, L. (2013). Beyond the business case: An ethical perspective of diversity training. Human Resource Management, 52(1), $55-74$.

Jones, D. A., Willness, C. R., \& Madey, S. (2014). Why are job seekers attracted by corporate social performance? Experimental and field tests of three signal-based mechanisms. Academy of Management Journal, 57(2), 383-404.

Jordan, N. (2009). Schopenhauer's politics: Ethics, Jurisprudence and the State. In A. Neill \& C. Janaway (Eds.), Better consciousness: Schopenhauer's philosophy of value (pp. 171-188). Hoboken: Wiley-Blackwell.

Kaptein, M. (2008a). Developing a measure of unethical behavior in the workplace: A Stakeholder perspective. Journal of Management, 34(5), 978-1008.

Kaptein, M. (2008b). Developing and testing a measure for the ethical culture of organizations: The corporate ethical virtues model. Journal of Organizational Behavior, 29(7), 923-947.

Kaptein, M., \& Wempe, J. (2002). The balanced company: A theory of corporate integrity. OUP Catalogue.

Kelly, E., \& Dobbin, F. (1998). How affirmative action became diversity management: Employer response to antidiscrimination law, 1961 to 1996. American Behavioral Scientist, 41(7), 960-984.

Klonoski, R. J. (1991). Foundational considerations in the corporate social responsibility debate. Business Horizons, 34(4), 9-18.

Lauring, J. (2013). International diversity management: Global ideals and local responses. British Journal of Management, 24(2), 211-224.

Lii, Y.-S., \& Lee, M. (2012). Doing right leads to doing well: When the type of CSR and reputation interact to affect consumer evaluations of the firm. Journal of Business Ethics, 105(1), 69-81.

Lin, C.-P., Lyau, N.-M., Tsai, Y.-H., Chen, W.-Y., \& Chiu, C.-K. (2010). Modeling corporate citizenship and its relationship with organizational citizenship behaviors. Journal of Business Ethics, 95(3), 357-372.

Livesey, S. M. (2001). Eco-identity as discursive struggle: Royal dutch/shell, brent spar, and Nigeria. Journal of Business Communication, 38(1), 58-91. 
Luo, X., \& Bhattacharya, C. B. (2006). Corporate social responsibility, customer satisfaction, and market value. Journal of Marketing, 70(4), 1-18.

Lynch, T. (2009). Legitimating market egoism: The availability problem. Journal of Business Ethics, 84(1), 89-95.

Mander, J. (1992). The myth of the corporate conscience. Business and Society Review, 81, 56-63.

Martín-Alcázar, F., Romero-Fernández, P. M., \& Sanchez, G. (2013). Workforce diversity in strategic human resource management models: A critical review of the literature and implications for future research. Cross Cultural Management: An International Journal, 20(1), 39-49.

Matten, D., \& Moon, J. (2008). "Implicit" and "explicit" CSR: A conceptual framework for a comparative understanding of corporate social responsibility. Academy of Management Review, 33(2), 404-424.

McGuire, J. B., Alison, S., \& Schneeweis, T. (1988). Corporate social responsibility and firm financial performance. The Academy of Management Journal, 31(4), 854-872.

McWilliams, A., \& Siegel, D. (2001). Corporate social responsibility: A theory of the firm perspective. The Academy of Management Review, 26(1), 117-127.

Mestrovic, S. G. (1989). Moral theory based on the 'heart' versus the 'mind': Schopenhauer's and Durkheim's critiques of Kantian ethics. The Sociological Review, 37(3), 431-457.

Moon, J. (2007). The contribution of corporate social responsibility to sustainable development. Sustainable Development, 15(5), 296-306.

Moore, G. (1999). Corporate moral agency: Review and implications. Journal of Business Ethics, 21(4), 329-343.

Morsing, M., \& Schultz, M. (2006). Corporate social responsibility communication: Stakeholder information, response and involvement strategies. Business Ethics: A European Review, 15(4), 323-338.

Nielsen, A. E., \& Thomsen, C. (2009). Investigating CSR communication in SMEs: A case study among Danish middle managers. Business Ethics: A European Review, 18(1), 83-93.

Organ, D. W. (1988). Organizational citizenship behavior: The good soldier syndrome. Lanham: Lexington Books.

Phillips, A. (2004). Defending equality of outcome. Journal of Political Philosophy, 12(1), 1-19.

Roberson, Q. M., \& Park, H. J. (2007). Examining the link between diversity and firm performance: The effects of diversity reputation and leader racial diversity. Group and Organization Management, 32(5), 548-568.

Robinson, G., \& Dechant, K. (1997). Building a business case for diversity. The Academy of Management Executive (1993-2005), 11(3), 21-31.

Schopenhauer, A. (1841a). On the basis of morality (E. F. J. Payne, Trans.). Indianapolis and Cambridge: Hackett Publishing Company.

Schopenhauer, A. (1841b). The two fundamental problems of ethics (D. E. Cartwright \& E. E. Erdmann, Trans.). New York: Oxford University Press.
Scott, S. (2007). Corporate social responsibility and the fetter of profitability. Social Responsibility Journal, 3(4), 31-39.

Shaw, W. (2009). Marxism, business ethics, and corporate social responsibility. Journal of Business Ethics, 84(4), 565-576.

Simpson, A. V., Clegg, S., \& Pitsis, T. (2014). "I Used to Care but Things Have Changed": A genealogy of compassion in organizational theory. Journal of Management Inquiry, 23, 347-359.

Singal, M. (2014). The business case for diversity management in the hospitality industry. International Journal of Hospitality Management, 40, 10-19.

Smith, C. A., Organ, D. W., \& Near, J. P. (1983). Organizational citizenship behavior: Its nature and antecedents. Journal of Applied Psychology, 68(4), 653-663.

Solomon, R. C. (1992). Ethics and excellence: Cooperation and integrity in business. New York: Oxford University Press.

Solomon, R. C. (1998). The moral psychology of business: Care and compassion in the corporation. Business Ethics Quarterly, 8(3), $515-533$.

Tatli, A. (2011). A multi-layered exploration of the diversity management field: Diversity discourses, practices and practitioners in the UK. British Journal of Management, 22(2), 238-253.

Tatli, A., Vassilopoulou, J., Ariss, A. A., \& Özbilgin, M. (2012). The role of regulatory and temporal context in the construction of diversity discourses: The case of the UK, France and Germany. European Journal of Industrial Relations, 18(4), 293-308.

Treviño, L. K., \& Weaver, G. R. (2003). Managing ethics in business organizations: Social scientific perspectives. Redwood City: Stanford University Press.

Treviño, L. K., Weaver, G. R., \& Reynolds, S. J. (2006). Behavioral ethics in organizations: A review. Journal of Management, 32(6), 951-990.

Valor, C. (2005). Corporate social responsibility and corporate citizenship: Towards corporate accountability. Business and Society Review, 110(2), 191-212.

Velasquez, M. (2002). Moral reasoning. In N. E. Bowie (Ed.), The blackwell guide to business ethics (pp. 102-116). Oxford: Blackwell.

Velasquez, M. (2003). Debunking corporate moral responsibility. Business Ethics Quarterly, 13(4), 531-562.

Ven, B. (2008). An ethical framework for the marketing of corporate social responsibility. Journal of Business Ethics, 82(2), 339-352.

Weber, M. (2008). The business case for corporate social responsibility: A company-level measurement approach for CSR. European Management Journal, 26(4), 247-261.

Werhane, P. H. (1985). Persons, rights, and corporations. Englewood Cliffs: Prentice-Hall.

Werhane, P. H. (1989). Corporate and individual moral responsibility: A reply to Jan Garrett. Journal of Business Ethics, 8(10), $821-822$.

Wolf, S. (1985). The legal and moral responsibility of organizations. In J. R. Penncock \& J. W. Chapman (Eds.), Criminal justice (pp. 267-286). New York: New York University Press. 